\title{
Pengaruh Urutan Kelahiran pada Kecemasan Mahasiswa Sekolah Tinggi Ilmu Komunikasi X Jakarta
}

\author{
Untung Subroto ${ }^{1}$, Monty P. Satiadarma ${ }^{2}$ dan Linda Wati ${ }^{3}$ \\ ${ }^{1}$ Fakultas Psikologi, Universitas Tarumanagara Jakarta \\ Email:untungs@fpsi.untar.ac.id \\ ${ }^{2}$ Fakultas Psikologi, Universitas Tarumanagara Jakarta \\ Email: montys@fpsi.untar.ac.id \\ ${ }^{3}$ Fakultas Psikologi, Universitas Tarumanagara Jakarta \\ Email: lindaw@fpsi.untar.ac.id
}

\begin{abstract}
ABSTRAK
Adler mengatakan kepribadian juga dapat ditentukan dengan melihat urutan kelahiran. Setiap anak memiliki kecemasan yang ditimbulkan karena urutan kelahiran tersebut. Terdapat 2 jenis kecemasan yang sering dipakai state dan trait anxiety. Tujuan penelitian ini adalah untuk mendeskripsikan kecemasan berdasarkan urutan kelahiran, dan melihat masalah anak berdasarkan perannya sebagai anak tertua, tengah, bungsu atau tunggal. Penelitain ini menggunakan pendekatan kuantitatif deskriptif pada 100 mahasiswa Sekolah Tinggi Ilmu Komunikasi X Jakarta. Berdasarkan analisis data, ditemukan bahwa secara umum baik untuk dimensi stait dan trait semua partisipan memiliki kecemasan yang rendah. Berdasarka dimensi state, anak tunggal memiliki tingkat kecemasan lebih tinggi dibandingkan anak dengan urutan lahir lainnya $(M=2.27, S D=0.66)$. Kemudian tingkat kecemasan tertinggi kedua adalah anak sulung $(M=2.14, S D=0.51)$. lalu anak tengah $(M=2.10, S D=0.52)$, dan yang terakhir adalah anak bungsu $(M=2.04, S D=0.42)$. Hal ini dapat diartikan bahwa anak tunggal memiliki kecenderungan akan kecemasan yang lebih tinggi secara subyektif dibandingkan dengan anak anak tengah, sulung dan bungsu. Berdasarkan analisis, data juga ditemukan bahwa pada dimensi trait, anak tengah dan anak bungsu memiliki tingkat kecemasan lebih tinggi dibandingkan dengan anak sulung dan anak tunggal. Anak tengah memiliki skor mean 2.31 dengan standar deviasi sebesar 0. 49. Anak bungsu memiliki skor mean 2.31 dengan standar deviasi sebesar 0.41. Sedangkan skor mean pada anak sulung adalah 2.30 dengan standar deviasi sebesar 0.36 dan anak tunggal memiliki skor mean 2.26 dengan standar deviasi sebesar 0.59. Hal ini dapat diartikan bahwa anak tengah dan bungsu memiliki kecenderungan memiiliki kecemasan yang sifatnya relatif menetap dan penghayatan kecemasannya cenderung sebagai sifat dari kepribadian.
\end{abstract}

Kata kunci: kecemasan, state, trait, urutan kelahiran.

\section{PENDAHULUAN}

Setiap anak dalam keluarga memiliki keunikan dan sifat sendiri, misalnya anak sulung yang sempat menjadi anak tunggal selama beberapa waktu akan mengalami penurunan posisi yang traumatis ketika saudara yang lebih muda lahir. Peristiwa ini secara dramatis mengubah situasi dan cara pandang anak terhadap dunia (Adler dalam Fiest \& Fiest, 2009). Saat anak pertama lahir, semua waktu dan perhatian orang tuanya akan tercurah hanya kepada anak tersebut, sehingga anak merasa mendapatkan hak yang istimewa dari orang tuanya. Ketika anak kedua atau anak seterusnya lahir maka perhatian akan lebih tercurahkan kepada anak yang baru saja lahir. Dalam kondisi seperti itu maka anak pertama atau anak yang lahir sebelumnya akan merasa orang tuanya tiba-tiba tidak memiliki waktu bermain serta kasih sayang yang lebih. Anak pertama merasa jika kehadiran adik merebut orang tuanya sehingga terjadilah penolakan akan lahirnya adik. Berbagai cara dilakukan anak pertama untuk mendapatkan kembali perhatian dari kedua orangtuanya, akan tetapi cara yang digunakan seringkali berupa perilaku negatif. Tidak jarang orangtua akan marah pada kakak, tanpa menyadari bahwa adik yang salah dan hal ini membuat kakak menjadi sedih. Pola asuh yang diterapkan orang tua di rumah, mempengaruhi kecenderungan seorang anak untuk bersaing dengan saudara kandungnya. Sibling rivalry muncul ketika hanya ada salah satu anak kesayangan orang tua, karena hal ini yang akan menimbulkan masalah jangka panjang dalam hubungan kakak beradik yaitu kecemasan.

Hubungan yang tidak harmonis antara kakak dan adik, dan pola asuh yang tidak seimbang antara kakak dan adik yang diterapkan oleh orang tua pada anak akan menimbulkan kecemasan. Freud 
(dalam Fiest and Fiest, 2009) mengatakan kecemasan adalah situasi efektif yang dirasa tidak menyenangkan yang diikuti oleh sensasi fisik yang memperingatkan bahwa seseorang dalam bahaya yang mengancam. Perasaan tidak menyenangkan ini biasanya samar-samar dan sulit dipastikan, tetapi selalu dapat dirasakan. Sementara Spielberger (dalam Lalita, 2014) kecemasan adalah emosi yang terdiri pikiran-pikiran tidak menyenangkan, sensasi tidak menyenangkan, dan perubahan fisik yang terjadi dalam menanggapi situasi atau stimulus yang dianggap mengancam atau berbahaya.

Kecemasan dapat mempengaruhi berbagai macam aspek kehidupan seseorang. Pada penelitian yang dilakukan oleh Auliani (2010) yang melakukan penelitian untuk melihat hubungan tipe kecemasan dengan prestasi belajar pada mahasiswa Fakultas Psikologi Universitas Islam Negeri Jakarta menyimpulkan ada hubungan yang signifikan antara kecemasan dengan perestasi belajar mahasiswa.

Kecemasan juga dapat berdampak pada perilaku agresif. Pada penelitian yang dilakukan oleh Mu'arifah (2005) yang melakukan penelitian untuk melihat hubungan kecemasan dan agresivitas menyimpulkan, ada hubungan antara kecemasan dengan agresivitas pada mahasiswa. Berdasarkan penelitian tersebut disimpulkan bahwa kecemasan mempengaruhi agresivitas pada masa remaja dan kecemasan merupakan salah satu penyebab remaja melakukan agresivitas.

Fenomena tentang urutan kelahiran, kecemasan dan perilaku agresif dapat tergambar pada kasus yang terjadi di Purwakarta, D (48 tahun) pemilik bengkel motor, di Kampung Cikukulu, RT 19/10, Desa Slawi, Kecamatan Pasawahan, Kabupaten Purwakarta, dibunuh adik kandungnya M. Menurut Kasat Reskrim Polres Purwakarta AKP Tri Suhartanto yang menangani kasus ini, motif pelaku tega membunuh kakak kandunya karena iri hati, sebab D hidup lebih sukses sementara M hanya seorang pengganguran (Jalaludin, 2015).

Berbicara mengenai urutan kelahiran, Adler (dalam Fiest and Fiest, 2009) mengatakan anak sulung kemungkinan besar memiliki perasaan berkuasa dan superioritas yang kuat, kecemasan yang tinggi, serta kecenderungan memiliki sifat overprotektif. Anak sulung memiliki sifat positif antara lain kemampuan untuk merawat dan melindungi orang lain, organisator yang baik. Sementara sifat negatif anak sulung antara lain memiliki kecemasan yang tinggi, memiliki perasaan berkuasa yang berlebihan, permusuhan secara tidak sadar, berjuang untuk mendapatkan pengakuan, merasa paling benar, mudah mengkritik orang lain dan tidak bisa bekerja sama.

Menurut Adler (dalam Fiest and Fiest, 2009) kepribadian anak kedua dibentuk oleh persepsi mereka akan sikap anak sulung terhadap mereka. Jika sikap yang ditunjukkkan anak sulung adalah permusuhan dan balas dendam yang berlebihan, maka anak kedua mungkin akan menjadi kompetitif atau sangat berkecil hati, atau sebaliknya anak kudua mungkin akan memiliki daya saing yang cukup serta keinginan sehat untuk mengalahkan saingan yaitu kakaknya. Anak kedua biasanya memiliki sifat positif yaitu memiliki motivasi yang tinggi, bisa bekerja sama serta memiliki daya saing yang cukup. Adler juga menambahkan anak kedua memiliki sifat negatif mudah merasa berkecil hati dan kadang-kadang daya saing yang terlalu tinggi.

Anak bungsu diyakini oleh Adler (dalam Fiest and Fiest, 2009) biasanya paling dimanja dan konsekuensinya memiliki risiko tinggi menjadi anak yang berasalah. Mereka sering memiliki perasaan inferior yang kuat dan kurang mandiri. Anak bungsu juga memiliki beberapa kelebihan, antara lain anak bungsu sering memiliki motivasi cukup tinggi untuk melebihi kakak-kakaknya. 
Anak bungsu juga memiliki ambisi yang realistis dan memiliki sifat negatif antara lain gaya hidup yang manja, bergantung pada orang lain, ingin selalu unggul dalam segala hal.

Sementara anak tunggal berada dalam kondisi paling unik dalam hal daya saing, yaitu tidak bersaing dengan saudara-saudaranya tetapi terhadap ayah dan ibunya. Anak tunggal sering membentuk rasa superior yang tinggi dan konsep diri yang berlebihan. Adler juga menambahkan anak tunggal kurang memiliki sifat kerja sama dan minat sosial, bersikap parasit, mengharapkan orang lain untuk memanjakan dan melindungi diri mereka dan memiliki cara hidup manja.

Menurut Spielberger (dalam Tania 2014), kecemasan adalah emosi yang terdiri pikiran-pikiran tidak menyenangkan, sensasi tidak menyenangkan, dan perubahan fisik yang terjadi dalam menanggapi situasi atau stimulus yang dianggap mengancam atau berbahaya. Terdapat dua dimensi dalam kecemasan menurut Spielberger yaitu state anxiety, yang dapat dikonseptualisasikan sebagai keadaan emosional sementara. Kondisi ini ditandai oleh perasaan subyektif dengan mengalami ketegangan dan ketakutan, saat berada pada kondisi yang mengancam maka state axiety meningkat dan akan menurun apabila terlepas dari suatu obyek yang mengancam. State anxiety dikonseptualisasikan sebagai kondisi psikologis, biologis, dan emosional yang ditandai dengan timbulnya rasa tegang, gugup, ketakutan, dan kekhawatiran yang bervariasi dalam intensitas yang tidak menentu dari waktu ke waktu (fluktuatif), artinya, kadar kecemasan akan meningkat pada keadaan yang dianggap mengancam dan akan menurun pada keadaan yang tidak menekan atau dianggap tidak membahayakan. Persepsi tentang membahayakan atau tidaknya suatu keadaan dipengaruhi oleh kecenderungan kepribadian seseorang dan pengalaman yang dimiliki atau dipelajari pada waktu yang lalu. Menurut Spielberger (dalam Tania, 2014) state anxiety adalah proses atau reaksi empiris yang terjadi saat ini pada level intensitas tertentu. Kecemasan ini dikarakteristikkan dengan perasaan yang dirasakan secara sadar, subyektif mengenai kecemasan dan tekanan. State anxiety menyebabkan reaksi perilaku langsung melalui mekanisme pertahanan dan proses adaptif untuk menghindari situasi stress

Selanjutnya terdapat trait anxiety, mengacu pada perbedaan pandangan dalam menghadapi suatu kecemasan, relatif stabil dibanding dengan state anxiety. Menurut Spielberger (dalam Tania, 2014) state anxiety adalah proses atau reaksi empiris yang terjadi saat ini pada level intensitas tertentu. Kecemasan ini dikarakteristikkan dengan perasaan yang dirasakan secara sadar, subyektif mengenai kecemasan dan tekanan. Trait anxiety diinterpretasikan sebagai pengukuran perbedaan individu yang stabil dalam karakteristik keperibadian yang relatif permanen. Trait anxiety mengacu pada perbedaan pandangan dalam menghadapi suatu kecemasan, relatif stabil dibanding kecemasan state. Kecemasan trait langsung mempengaruhi penilaian kognitif seseorang, yang berdampak pada bagaimana seorang individu memandang situasi stres. Trait anxiety (kecemasan dasar) merupakan kecemasan yang sifatnya relatif menetap dan penghayatan kecemasannya cenderung sebagai sifat dari kepribadian. Trait anxiety mengacu pada perbedaan kestabilan individu dan bagaimana individu menampilkan respon terhadap situasi yang menyebabkan kecemasan. Walaupun sedang berada dalam kondisi yang rawan terhadap kecemasan, bagaimana individu dapat merespon situasi yang menimbulkan kecemasan merupakan ciri dari kepribadian.

Kecemasan yang terus berlangsung dalam hidup seseorang akan mempengaruhi kesehatan baik secara fisik atau psikologis. Kecemasan berbeda dengan rasa takut. Rasa takut biasanya diikuti oleh obyek yang mengancam. Ketakutan dapat berkembang menjadi kecemasan yang menetap. Kecemasan yang serius dapat menyebabkan beberapa gangguan antara lain gangguan panik, 
fobia, separation anxiety dll (Hoeksema 2014). Kecemasan dapat terjadi mulai dari usia anakanak hingga dewasa. Anak-anak dapat mengembangkan perasaan cemas ketika terpisah dengan pengasuhnya. Perasaan ini kemudian menyebabkan anak tumbuh menjadi anak yang pemalu, sensitif dan bergantung pada pengasuh. Sementara lebih dari $15 \%$ orang tua yang berumur lebih dari 65 tahun juga mengalami kecemasan yang berhubungan dengan kehilangan orang yang dicintai, karena masalah kesehatan dan perasaan tidak aman (Hoeksema 2014). Terdapat beberapa penyebab seseorang mengalami kecemasan diantaranya pengaruh lingkungan dan faktor sosial termasuk kondisi dalam keluarga termasuk urutan kelahiran. Berdasarkan uraian tentang urutan kelahiran pada anak yang mempengaruhi kepribadian anak termasuk kecemasan, sementara kecemasan pada individu berpengaruh pada kondisi kesehatan fisik dan psikologis individu, maka penelitian ini dilakukan untuk mendeskripsikan pengaruh urutan kelahiran pada kecemasan.

\section{METODE PENELITIAN}

Partisipan penelitian ini adalah mahasiswa dan mahasiswi dari Sekolah Tinggi Ilmu Komunikasi $\mathrm{X}$ di Jakarta Indonesia. Pemilihan partisipan penelitian tidak dibatasi oleh agama, etnis, sosial ekonomi dan jenis kelamin. Jumlah partisipan penelitian 100 dari berbagai macam jurusan. Jenis penelitian ini adalah kuantitatif. Metode pengambilan data dengan memberikan kuisioner STAI dari Spielberger yang telah diadaptasi oleh Fakultas Psikologi Universitas Tarumanagara. Selain memberikan kuisioner STAI, peneliti juga memberika kuisioner yang berisi pertanyaan tentang masalah yang sering dialami partisipan sehubungan dengan perannya menjadi anak sulung, tengah, bungsu dan tunggal. Penelitian ini dilakukan dengan tujuan untuk mendeskripsikan kecemasan anak berdasarkan urutan kelahiran anak. Pengolahan data statistik deskriptif dengan menggunakan teknik SPSS untuk mendeskripsikan kecemasan pada setiap anak berdasarkan urutan kelahiran.

Tabel 1. Gambaran subyek berdasarkan jenis kelamin

\begin{tabular}{ccc}
\hline Jenis Kelamin & Frekuensi & Persentase \\
\hline Laki-Laki & 10 & 10.0 \\
Perempuan & 90 & 90.0 \\
\hline Total & 100 & 100.0 \\
\hline
\end{tabular}

Tabel 2. Gambaran subyek berdasarkan urutan kelahiran

\begin{tabular}{ccc}
\hline Urutan Kelahiran & Frekuensi & Persentase \\
\hline Anak Sulung & 36 & 36.0 \\
Anak Tengah & 14 & 14.0 \\
Anak Bungsu & 42 & 42.0 \\
Anak Tunggal & 8 & 8.0 \\
\hline Total & 100 & 100.0 \\
\hline
\end{tabular}

\section{HASIL PENELITIAN DAN PEMBAHASAN}

Berdasarkan hasil perhitungan, ditemukan bahwa secara umum tingkat kecemasan partisipan pada dimensi state $(M=2.10, S D=0.48)$ maupun trait $(M=2.30, S D=0.41)$ tergolong rendah karena keduanya memiliki skor mean lebih rendah dari 2.5. 
Tabel 3. Gambaran variabel penelitian

\begin{tabular}{ccccc}
\hline Dimensi & Minimum & Maksimum & Mean & SD \\
\hline STATE & 1.15 & 3.85 & 2.10 & 0.48 \\
TRAIT & 1.26 & 3.47 & 2.30 & 0.41 \\
\hline
\end{tabular}

Berdasarkan hasil analisa data statistik, ditemukan bahwa pada dimensi state, anak tunggal memiliki tingkat kecemasan tertinggi dibandingkan dengan anak dengan urutan lahir lainnya $(\mathrm{M}=2.27, \mathrm{SD}=0.66)$. Kemudian tingkat kecemasan tertinggi kedua adalah anak sulung $(\mathrm{M}=2.14$, $\mathrm{SD}=0.51)$, lalu anak tengah $(\mathrm{M}=2.10, \mathrm{SD}=0.52)$, dan yang terakhir adalah anak bungsu $(\mathrm{M}=2.04$, $\mathrm{SD}=0.42$ ). Sementara berdasarkan hasil analisa data statistik, ditemukan bahwa pada dimensi trait, anak tengah dan anak bungsu memiliki tingkat kecemasan tertinggi dari pada anak sulung dan anak tunggal. Anak tengah memiliki skor mean 2.31 dengan standar deviasi sebesar 0. 49. Anak bungsu memiliki skor mean 2.31 dengan standar deviasi sebesar 0.41. Sedangkan skor mean pada anak sulung adalah 2.30 dengan standar deviasi sebesar 0.36 dan anak tunggal memiliki skor mean 2.26 dengan standar deviasi sebesar 0.59 .

Pada dimensi state, dikatakan bahwa anak tunggal memiliki tingkat kecemasan tertinggi, hal ini dapat diartikan bahwa anak tunggal memiliki tingkat kecemasan yang lebih tinggi secara subyektif dibandingkan denga anak anak tengah, sulung dan bungsu. Secara subjektif anak tunggal memiliki kecenderungan mudah cemas dengan kondisi psikologis, biologis, dan emosional yang ditandai dengan timbulnya rasa tegang, gugup, ketakutan dibandingkan dengan anak tengah, sulung dan bungsu.

Sementara pada dimensi trait, anak tengah dan bungsu memiliki kecemasan tertinggi dibandingkan dengan anak yang lain. Hal ini dapat diartikan bahwa anak tengah dan bungsu memiliki kecenderungan kecemasan yang sifatnya relatif menetap dan penghayatan kecemasannya cenderung sebagai sifat dari kepribadian. Anak tengah dan bungsu memiliki perbedaan kestabilan dalam menampilkan respon terhadap situasi yang menyebabkan kecemasan, anak tengah dan bungsu cenderung lebih cemas dibandingakan dengan anak tunggal dan anak sulung. Anak tengah dan bungsu dapat dikatakan memiliki kecenderungan berkepribadian yang pencemas.

Tabel 4. Gambaran kecemasan

\begin{tabular}{cccccc}
\hline Dimensi & Urutan & Minimum & Maksimum & Mean & SD \\
\hline \multirow{2}{*}{ STATE } & Anak Sulung & 1.30 & 3.25 & 2.14 & 0.51 \\
& Anak Tengah & 1.50 & 3.25 & 2.10 & 0.52 \\
& Anak Bungsu & 1.15 & 2.70 & 2.04 & 0.42 \\
& Anak Tunggal & 1.85 & 3.85 & 2.27 & 0.66 \\
\hline \multirow{2}{*}{ TRAIT } & Anak Sulung & 1.79 & 3.16 & 2.30 & 0.36 \\
& Anak Tengah & 1.68 & 3.37 & 2.31 & 0.49 \\
& Anak Bungsu & 1.26 & 3.11 & 2.31 & 0.41 \\
& Anak Tunggal & 1.74 & 3.47 & 2.26 & 0.59 \\
\hline
\end{tabular}

Berdasarkan hasil analisa uji beda antara partisipan laki-laki dan perempuan pada dimensi state anxiety diperoleh hasil tidak ada perbedaan pada anak sulung. Sementara untuk anak bungsu perempuan memiliki kecemasan lebih tinggi dibandingkan bungsu laki-laki pada dimensi state axiety. Hal ini dapat diartikan anak sulung baik perempuan atau laki-laki memiliki kesamaan mudah cemas ketika dihadapkan pada situasi stresor. Sementara untuk anak bungsu perempuan 
memiliki kecenderungan mudah cemas jika berhadapan dengan situasi stres dibandingkan anak bungsu laki-laki.

Tabel 5. Gambaran state anxiety berdasarkan jenis kelamin dan urutan kelahiran

\begin{tabular}{ccccc}
\hline \multirow{2}{*}{ Urutan Kelahiran } & \multicolumn{4}{c}{ Jenis Kelamin } \\
\cline { 2 - 5 } & \multicolumn{2}{c}{ Laki-laki } & \multicolumn{2}{c}{ Perempuan } \\
\cline { 2 - 5 } & Mean & SD & Mean & SD \\
\hline Sulung & 2.12 & 0.50 & 2.15 & 0.51 \\
Tengah & 1.53 & - & 2.14 & 0.51 \\
Bungsu & 2.19 & 0.32 & 2.02 & 0.43 \\
Tunggal & 1.85 & - & 2.33 & 0.69 \\
\hline
\end{tabular}

Pada dimensi trait anxiety, anak sulung dan bungsu laki-laki lebih lebih cemas dibandingkan dengan anak sulung dan bungsu perempuan. Hal ini dapat diartikan anak sulung dan bungsu lakilaki memiliki kecenderungan memiliki kepribadian pencemas dibandingkan anak perempuan.

Tabel 6. Gambaran trait anxiety berdasarkan jenis kelamin dan urutan kelahiran

\begin{tabular}{ccccc}
\hline \multirow{3}{*}{ Urutan Kelahiran } & \multicolumn{4}{c}{ Jenis Kelamin } \\
\cline { 2 - 5 } & \multicolumn{2}{c}{ Laki-laki } & \multicolumn{2}{c}{ Perempuan } \\
\cline { 2 - 5 } & Mean & SD & Mean & SD \\
\hline Sulung & 2.35 & 0.44 & 2.30 & 0.36 \\
Tengah & 2.26 & - & 2.31 & 0.51 \\
Bungsu & 2.48 & 0.26 & 2.29 & 0.42 \\
Tunggal & 1.89 & - & 2.32 & 0.62 \\
\hline
\end{tabular}

Berdasarkan pengolahan kuisioner tentang masalah yang dihadapi oleh anak sulung, tengah, bungsu dan tunggal pada penelitian ini, 36 anak sulung merasa memiliki perasaan tidak menyenangkan yang berhubungan dengan urutan dalam kelahiran antara lain sering dibandingbandingkan (4.26\%), disuruh-suruh (4.26\%), memiliki tanggung jawab lebih besar (12.77\%), merasa banyak tuntutan (17.02\%), sering disalahkan $(17.02 \%)$, dan harus sering mengalah $(19.15 \%)$, lain-lain (25.53). Hal ini terjadi karena keberadaan anak sulung dalam keluarga merupakan role model bagi anak-anak yang lain. Keberhasilan atau kegagalan pada anak sulung akan mempengaruhi anak-anak yang lain. Orang tua memiliki ekspektasi yang cukup besar pada anak sulung karena anak sulung merupakan contoh bagi anak yang lain, sehinga hal ini dirasakan anak sulung sebagai sebuah tanggung jawab yang harus ditanggung.

Sementara anak tengah yang berjumlah 14 responden merasa selalu disuruh-suruh (7.69\%), dituntut mandiri (7.69\%), harus mengalah (7.69\%), harus berperan ganda $(7.69 \%)$, sering berkelahi dengan adik (7.69\%), sering dimarahi (7.69\%), diabaikan (15.38\%), lain-lain (38.465). Perasaan ini muncul karena keberadaan anak tengah yang merasa memiliki pesaing yang cukup kuat yaitu kakak sulung. Kakak sulung yang memiliki sifat superior menyebabkan anak tengah merasa selalu mengalah dan dituntut untuk menuruti apa yang dikatakan oleh kakak sulung. Hal ini tentu saja bergantung pada bagaimana hubungan antara anak tengah dan kakak sulungnya. Jika hubungan antara mereka tidak harmonis menyebabkan anak tengah menjadi anak yang inferior, jika hubungan keduanya sehat, anak sulung akan mengembangkan sifat kompetitif yang sehat dengan kakak sulungnya. 
Sementara responden anak bungsu yang berjumlah 42 orang merasa memiliki perasaan antara lain, sulit dipercaya (2.67\%), dibanding-bandingkan (4.00\%), mendapat barang bekas (4.00\%), sering mengalah $(4.00 \%)$, terlalu dimanja $(4.00 \%)$, sering ditindas $(5.33 \%)$, tidak diutamakan (5.33\%), harus mengikuti atau lebih baik dari kakak (6.67\%), dianggap rendah (14.675), disuruh-suruh (18.67\%), terlalu dikekang (18.6\%) dan lain-lain (12\%). Kondisi yang dirasakan oleh anak bungsu ini disebabkan karena sebagai anak paling muda dalam keluarga sering mendapatkan perlakuan dimanja oleh kakak dan orang tua, hal ini menyebabkan perasaan inferior dan merasa sering ditindas, sulit dipercaya dan dianggap rendah serta merasa dikekang. Sebagai anak tunggal yang berjumlah 8 , responden penelitian menganggap harus menanggung beban sendiri (11.11\%), tuntutan harapan orang tua (16.67\%), beban tanggung jawab (22.22\%), kesepian (38.8\%), dan lain-lain (11.11\%). Sebagai anak satu satunya dalam keluarga perasaan pada anak tunggal bukan bersumber pada persaingan dengan kakak-kakanya tetapi lebih pada perasaan kesendirian baik menanggung beban sendiri atau perasaan sendiri karena tidak memiliki saudara dalam keluarga. Sebagai anak satu-satunya, orang tua juga berharap besar pada keberhasilan anak tunggal, sehingga hal ini menimbulkan perasaan memiliki beben dan tanggung jawab yang besar.

Temuan pada penelitian ini berdasarkan kuisioner tentang masalah menjadi anak sulung, tengah, bungsu dan tunggal adalah penelitian juga disimpulkan terdapat $19.15 \%$ anak sulung merasa harus mengalah dengan saudara lainnya. Hal ini disebabkan karena sebagai anak sulung, mereka merasa harus memberikan role model pada saudara lainnya. Terdapat $15.38 \%$ anak tengah merasa diabaikan. Persentase ini menunjukan bahwa sebanyak $15.38 \%$ anak tengah pada penelitian ini merasa tidak mendapatkan perhatian yang cukup dari orang tua mereka. Perasaan ini juga dapat ditimbulkan karena sikap permusuhan antara anak tengah dengan kakak yang membuat anak tengah merasa inferior dan berkecil hati. Terdapat $18.67 \%$ partisipan anak bungsu pada penelitian ini yang merasa disuruh-suruh oleh kakak. Hal ini disebabkan karena sebagai anak bungsu merasa inferior sehingga merasa tidak dapat menolak ketika diperintah oleh kakak tertua atau kakak tengah. Terdapat juga $18.6 \%$ anak bungsu pada penelitian ini yang merasa terkekang, hal ini disebabkan karena sebagai anak bungsu sebagian besar anggota keluarga memberikan perlakuan memanjakan, pengawasan yang ketat, selalu dianggap sebagai anak kecil serta overprotektif pada anak bungsu sehingga menyebabkan anak bungsu merasa terkekang. Partsipan anak tunggal pada penelitain ini 38.8\% merasa kesepian, hal ini dapat disebabkan karena sebagai anak tunggal yang tidak memiliki kakak dan adik, juga karena dapat disebabkan karena anak tunggal juga memiliki minat sosial yang rendah.

Kondisi tidak menyenangkan baik pada anak sulung, tengah, bungsu dan tunggal walaupun berbeda-beda bentuknya, dapat menimbulkan kecemasan. Kecemasan ini dapat dilihat pada ekspresi perilaku langsung yang merupakan mekanisme pertahanan dan proses adaptif untuk menghindari situasi stress atau merupakan ciri dari kepribadian.

\section{KESIMPULAN DAN SARAN}

Berdasarkan penelitian ini dapat disimpulkan bahwa tidak terdapat pengaruh kecemasan pada urutan kelahiran. Berdasarkan analisis data pula dapat dikatakan bahwa secara umum baik untuk dimensi stait dan trait semua partisipan memiliki kecemasan yang rendah. Walaupun partisipan memiliki tingkat kecemasan yang rendah, jika dilihat dari analisa hasil yaitu standar deviasi, dapat dikatakan anak tunggal memiliki kecenderungan tingkat kecemasan tertinggi dibandingkan dengan anak dengan urutan lahir lainnya pada dimensi state. Sementara untuk dimensi trait, anak tengah dan anak bungsu memiliki tingkat kecemasan tertinggi dibandingkan dengan anak sulung dan anak tunggal. 
Berdasarkan hasil penelitian di atas, ada beberapa saran yang dapat peneliti berikan. Pertama, karena kecemasan juga dipengaruhi oleh pengaruh lingkungan dan sosial termasuk urutan kelahiran dalam keluarga, sebaiknya orang tua tidak menciptakan potensi kecemasan yang akan terus berkembang dikemudian hari misalnya, membandingkan antara anak, mengaggap anak dengan urutan tertentu lebih baik dari anak yang lain. Orang tua sebaiknya berlaku adil pada setiap anak agar tidak menciptakan perasaan cemburu yang kemudian menciptakan kecemasan dikemudian hari. Kedua, setiap anak adalah unik jadi kepada subyek penelitian, jadilah diri sendiri dengan mengembangkan potensi yang dimiliki. Kakak atau adik bukanlah pesaing yang harus dicemaskan tetapi saling memberikan dukungan adalah tindakan yang harus dikembangakan dalam hubungan antar saudara. Ketiga, jika kecemasan terus berlangsung, hendaknya subyek penelitian meminta bantuan profesional yaitu psikolog untuk mendapatkan keterampilan meregulasi kesemasan yang dialami. Terakhir pada peneliti selanjutnya yang ingin melanjutkan atau mengembangkan penelitian ini, penambahan jumlah sample penelitian adalah saran yang dapat peneliti berikan untuk mendapatkan hasil yang lebih baik.

\section{REFERENSI}

Auliani, R. (2010). Hubungan antara tipe kecemasan dengan prestasi belajar statistik mahasiswa fakultas psikologi UIN Jakarta. Jakarta : Skripsi (tidak diterbitkan)

Feist, J. \& Feist, G, J. (2009). Theories of personality (7th ed.). New York: McGraw-Hill.

Jalaludin, D. (2015). Motif adik tega bunuh kakak kandungnya di Purwakarta terbongkar. News.okezone.com. Diambil dari : http://news.okezone.com/read/2015/03/08/340/1115428 /motif-adik-tega-bunuh-kakak-kandungnya-di-purwakarta-terbongkar.

Lalita, T. V. (2014). Hubungan antara self-efficacy dengan kecemasan pada remaja yang putus sekolah. Jurnal Psikologi Klinis dan Kesehatan Mental. 3 (2), 60-66.

Mu'arifah, A. (2005). Hubungan kecemasan dengan agresifitas. Humanitas: Indonesian Psychological Journal. 2 (2). 102-111.

Nolen, S. Hoeksema (2014). Abnormal psychology (6th ed). New York: McGraw-Hill. 